\title{
UPAYA MENINGKATKAN KINERJA BISNIS MELALUI KEUNGGULAN BERSAING (STUDI PADA PT RAILINK)
}

\author{
Ratna Sari ${ }^{1}$, Muslikh ${ }^{2}$, Nazwirman ${ }^{3}$
}

Ratnaasari52@gmail.com

Program Magister Manajemen Sekolah Pascasarjana Universitas YARSI

Received: 5 Oktober 2018

Final Acepted: 22 November 2018

Published Online: Desember 2018

Keywords:

Bussiness Perpormance, Competitive advantage,SEM

Corresponding Authors:

* Ratna Sari
Abstract

Millennial generation is a generation born between 1980 and 2000. The number of millennial in Indonesia now reaches almost half of Indonesia's population. As a country with $87.2 \%$ of its population Muslim, it is a potential market for halal restaurants. This paper describes the behavior of Muslim millennial consumers in restaurants that have halal certificates in Indonesia. Research with the approach of the theory of planned behavior or planned training theory proposed by Ajzen (1991). The method used is Structural Equation Modeling (SEM) which analyzed using AMOS 24 program. The results of this study show that subjective norms and behavioral control have significant positive effect on consumer consumption interest. Interest in consumer consumption has asignificant positive effect on consumer behavior. While consumer behavior control does not affect consumer behavior.

Copyright JEBA 2018., All rights reserved

\begin{abstract}
ABSTRAK
Tujuan dari penelitian ini adalah untuk mengetahui upaya meningkatkan kinerja bisnis melalui keunggulan bersaing yang dilihat dari inovasi produk dan kualitas pelayanan. Penelitian ini dilakukan di PT Railink. Jumlah responden yang digunakan sebagai sampel adalah 100 responden dan alat analisis yang digunakan adalah SEM Lisrel. Teknik penentuan sampel dalam penelitian ini menggunakan purposive sampling. Hasil analisis Inovasi Produk berpengaruh terhadap Keunggulan Bersaing. Kualitas Pelayanan berpengaruh terhadap Keunggulan Bersaing. Inovasi Produk berpengaruh terhadap Kinerja Bisnis. Kualitas Pelayanan berpengaruh terhadap Kinerjs Bisnis. Keunggulan Bersaing berpengaruh terhadap Kinerja Bisnis. Inovasi Produk dan Kualitas Pelayanan berpengaruh terhadap Kinerja Bisnis melalui Keunggulan Bersaing.
\end{abstract}

Kata Kunci: Kinerja Bisnis, Keunggulan bersaing, Structural equation model

\section{PENDAHULUAN}

PT Railink merupakan perusahaan pertama dan hingga kini masih menjadi satusatunya di Indonesia yang menyediakan jasa pengangkutan penumpang dan barang dari 
dan ke bandara dengan menggunakan moda transportasi Kereta Api (KA). Saat ini PT Railink telah mengoperasikan KA Bandara Kualanamu sejak tahun 2013, bersamaan dengan dioperasikannya Bandara Kualanamu. Pada tahun ini, tepatnya 2 Januari 2018, KA Bandara Soekarno-Hatta diresmikan oleh Presiden Republik Indonesia Ir.Joko Widodo dan mulai dioperasikan oleh PT Railink, yang menghubungkan ARS (Airport Railway Station) Bandara Soekarno-Hatta (BSH) dengan CRS (City Railway Station) di Stasiun Sudirman Baru, Jakarta, melalui Stasiun Bekasi, Stasiun Duri dan Stasiun Batu Ceper.

Semakin pesatnya perkembangan teknologi informasi di dunia ini membawa banyak dampak perubahan yang nyata baik ke arah positif maupun negatif yang mempengaruhi perindustrian di dunia menjadi semakin modern dengan lahirnya inovasiinovasi baik dalam produk, design, waktu yang semakin efisien, terkendali dan meningkatkan produktifitas. Kompleksitas dan tantangan yang dihadapi perusahaan menuntut perusahaan untuk memiliki inovasi produk yang tepat sehingga mampu bersaing dengan kompetitor baik dari perusahaan nasional maupun bersaing dengan perusahaan multinasional.

Dalam era globalisasi perusahaan dituntut agar bisa terus berinovasi, menghadirkan hal yang baru, yang unik, yang lebih efisien, dan lebih baik dari produk dan jasa sebelumnya. Suatu perusahaan dapat meraih sukses ketika dilihat dari faktor kualitas pelayanan, oleh karena itu pelayanan yang baik sangat mempengaruhi banyaknya jumlah pelanggan dalam suatu perusahaan.

Banyaknya aspek yang menjadi pertimbangan bagi konsumen dalam memilih suatu produk. Salah satu aspek penting yang dilihat ialah kualitas pelayanan yang dimiliki produk tersebut. Selain itu juga persaingan didunia bisnis saat ini sangat ketat, dimulai persaingan dalam harga, kualitas, dan hal terpenting adalah produknya sendiri (harus ada sesuatu yang baru). Karena suatu hal yang inovatif bukan hanya melahirkan sesuatu yang baru namun haruslah bermanfaat bagi orang lain, artinya sesuatu yang inovatif tersebut dapat berguna bagi inovator contohnya seperti dapat lebih menghemat, lebih efisien dalam pembuatan produk, dapat menghasilkan keuntungan dan berguna bagi orang lain (Widianti, 2013) Pelayanan dikatakan berkualitas atau memuaskan apabila pelayanan tersebut dapat memenuhi kebutuhan dan harapan masyarakat. Apabila masyarakat tidak puas terhadap 
suatu pelayanan yang disediakan, maka pelayanan tersebut dapat dipastikan tidak berkualitas atau tidak efisien. Karena itu kualitas pelayanan sangat penting dan selalu fokus kepada kepuasan konsumen. Organisasi pelayanan publik mempunyai ciri public accountability, dimana setiap warga Negara mempunyai hak untuk mengevaluasi kualitas pelayanan yang mereka terima. Untuk menilai kualitas suatu pelayanan akan mengalami kesulitasn jika tidak mempertimbangkan peran masyarakat sebagai penerima pelayanan dan aparat pelaksana pelayanan itu (Hardiyansyah, 2011).

Adanya kinerja yang buruk dari suatu organisasi bisnis perlu untuk dicari permasalahannya karena dengan kinerja yang buruk tentu akan mengancam keberlangsungan perusahaan itu sendiri sehingga perusahaan dituntut untuk terus berinovasi dengan strategi-strategi yang dapat mempertahankan kinerja atau bahkan dapat meningkatkan kinerja pemasaran perusahaan. Karena kinerja suatu bisnis merupakan segala sesuatu yang diinginkan oleh konsumen dalan produk ataupun jasa dengan memaksimalkan kualitas hasil yang nantinya diterima konsumen (Gilang Prasidya, 2014). Inovasi yang tinggi baik itu inovasi proses maupun inovasi produk akan meningkatkan kemampuan perusahaan menciptakan produk yang berkualitas.

Kualitas produk yang tinggi akan meningkatkan keunggulan bersaing perusahaan yang pada akhirnya berdampak pada kinerja perusahaan (Hartini, 2012). Saat perusahaan mampu menyajikan inovasi produk dan kualitas pelayanan yang bernilai bagi konsumen maka dapat menguntungkan bagi perusahan, hal tersebut dapat meningkatkan keunggulan bersaing bagi perusahaan.

Layanan merupakan kegiatan yang ditawarkan oleh penyedia jasa kepada konsumen, bisa berupa benda dan objek lainnya (Lovelock dan Wirtz, 2011) yang menyatakan Layanan adalah kegiatan ekonomi yang ditawarkan oleh salah satu pihak kepada pihak lain. Kualitas pelayanan ini dapat diartikan sebagai tingkat kepuasan konsumen. Sedangkan tingkat kepuasan konsumen ini sendiri dapat diperoleh dari perbandingan atas jenis pelayanan yang nyata diterima oleh konsumen dengan jenis pelayanan yang diharapkan oleh konsumen. Kualitas pelayanan ini menjadi penting karena akan berdampak langsung pada citra perusahaan. Kualitas pelayanan yang baik akan menjadi sebuah keuntungan bagi perusahaan. 
Berdasarkan latar belakang diatas saat perusahaan mampu menyajikan inovasi produk dan kualitas pelayanan yang bernilai bagi konsumen maka dapat menguntungkan bagi perusahaan, hal tersebut dapat meningkatkan keunggulan bersaing bagi perusahaan. Maka inovasi, kualitas pelayaan, dan keunggulan bersaing itu telah memberikan kontribusi pada kinerja bisnis perusahan. Dengan demikian tujuan dari penelitian ini ialah :

1. Untuk mengukur bagaimana pengaruh Inovasi Produk terhadap Keunggulan Bersaing PT Railink.

2. Untuk mengukur bagaimana pengaruh Kualitas Pelayaan terhadap Keunggulan Bersaing PT Railink.

3. Untuk mengukur bagaimana pengaruh Inovasi Produk terhadap Kinerja Bisnis PT Railink.

4. Untuk mengukur bagaimana pengaruh Kualitas Pelayanan terhadap Kinerj Bisnis PT Railink.

5. Untuk mengukur bagaimana pengaruh Keunggulan Bersaing terhadap Kinerja Bisnis PT Railink.

\section{KAJIAN TEORI}

\section{Inovasi Produk}

Inovasi produk menurut Hurley dan Hult (2004) adalah sebagai sebuah mekanisme perusahaan untuk beradaptasi dalam lingkungan yang dinamis, oleh karena itu perusahaan dituntut untuk mampu menciptakan pemikiran-pemikiran baru, gagasan-gagasan baru dan menawarkan produk yang inovatif serta peningkatan pelayanan yang memuaskan pelanggan. Menurut Gatignon dan Xuereb (1997) dalam inovasi produk terdapat tiga dimensi, yaitu :

a) Keunggulan produk;

b) Kesamaan produk;

c) Biaya produk.

Dalam persaingan global, perusahaan harus dapat memodifikasi produknya untuk menambah nilai dari produk yang dihasilkannya dan harus dapat memenuhi kebutuhan dan 
selera yang pas dengan konsumen. Inovasi produk merupakan sesuatu yang dapat dilihat dari kemajuan fungsional produk yang dapat membawa produk selangkah lebih maju dibandingkan dengan produk pesaing. Apabila produk tersebut mempunyai kelebihan yang dipandang sebagai nilai tambah bagi konsumen.

Menurut Kotler dan Armstrong (2004) ada tiga indikator inovasi produk yaitu kualitas produk, varian produk, serta gaya dan desain produk :

1) Kualitas Produk

Kemampuan suatu produk dalam melakukan fungsi-fungsinya, yang meliputi daya tahan, kehandalan, dan ketelitian yang dihasilkan.

2) Varian Produk

Sarana kompetitif untuk membedakan produk satu dengan yang lain, atau antara produk yang dimiliki dengan produk pesaing.

3) Gaya dan Desain Produk

Cara lain dalam menambah nilai bagi pelanggan. Gaya hanya menjelaskan penampilan produk tertentu, sedangkan desain memiliki konsep yang lebih dari gaya.

\section{Kualitas Pelayanan}

Kualitas pelayanan menjadi suatu keharusan yang harus dilakukan perusahaan agar dapat mampu bertahan dan tetap mendapat kepercayaan pelanggan. Kualitas pelayanan merupakan salah satu bagian dari stretegi manajemen pemasaran.

Menurut Parasuraman (2001) terdapat lima dimensi pokok dalam kualitas pelayanan sebagai berikut:

1) Bukti Fisik (Tangible)

Kemampuan suatu perusahaan dalam menunjukan aksistensinya kepada pihak eksternal, dimana penampilan dan kemampuan sarana dan prasarana fisik perusahaan dan keadaan lingkungan sekitarnya adalah bukti nyata pelayanan yang diberikan oleh pemberi jasa yang berkenaan dengan daya tarik fasilitas fisik (gedung), peralatan / perlengkapan yang lengkap (teknologi), dan material yang digunakan perusahaan bersih, serta penampilan dari karyawan rapi.

2) Reliabilitas (Reliability) 
Berkaitan dengan kemampuan perusahaan untuk memberikan pelayanan sesuai yang dijanjikan secara akurat dan terpercaya, kinerja harus sesuai dengan harapan pelanggan yang berarti ketepatan waktu, pelayanan yang sama untuk semua pelanggan tanpa kesalahan, sikap sempati dan dengan akurasi yang tinggi, memberikan informasi yang akurat, sehingga keterampilan, kemampuan dan penampilan dalam menyelesaikan pekerjaan yang diberikan sesuai dengan apa yang ditetapkan sehingga menimbulkan rasa percaya konsumen terhadap pelayanan yang diberikan.

3) Daya Tanggap (Responsiveness)

Berhubungan dengan kesediaan dan kemampuan karyawan untuk membantu para konsumen dan merespon permintaan mereka, serta menginformasikan kapan jasa akan diberikan dan kemudian memberikan jasa secara cepat.

4) Jaminan (Assurance)

Perilaku karyawan yang mampu menumbuhkan kepercayaan konsumen terhadap perusahaan dan perusahaan bisa menciptakan rasa aman bagi para konsumennya. Jaminan juga berarti bahwa para karyawan selalu bersikap sopan dan menguasai pengetahuan dan keterampilan yang dibutuhkan untuk menangani setiap pertanyaan atau masalah konsumen. Asuransi diartikan sebagai salah satu kegiatan menjaga kepastian atau menjamin keadaan dari apa yang dijamin atau suatu indikasi menimbulkan rasa percaya.

5) Empati (Empathy)

Menyatakan bahwa perusahaan memahami masalah para konsumennya dan bertindak demi kepentingan konsumen, serta memberikan perhatian personal kepada para konsumen dan memiliki jam operasi yang nyaman.

Kualitas pelayanan dipersepsikan baik dan memuaskan jika jasa yang diterima sesuai dengan yang diharapkan konsumen dan dipersepsikan sebagai kualitas yang ideal jika jasa yang diterima melampaui harapan konsumen. Hal tersebut berlaku sebaliknya jika pelayanan yang diterima tidak sesuai dengan yang diharapkan. Dengan demikian baik tidaknya kualitas pelayanan tergantung pada kemampuan penyedia jasa dalam memenuhi harapan konsumen secara konsisten. Kualitas pelayanan merupakan tingkat keunggulan 
(excellent) yang diharapkan dan pengendalian atas keunggulan tersebut untuk memenuhi kebutuhan konsumen. Dengan kata lain ada dua faktor utama yang mempengaruhi kualitas pelayanan, yaitu expected service dan perceived service (Tjiptono, 2014).

Menurut Gronroos (1990), mengatakan bahwa kualitas total suatu jasa terdiri dari tiga komponen utama, yaitu:

\section{1) Technical Quality}

Yang berkaitan dengan kualitas output jasa yang diterima pelanggan. Komponen ini dapat dijabarkan lagi menjadi tiga jenis yang meliputi :

a) Search quality, dapat dievaluasikan sebelum dibeli, misalnya harga.

b) Experince quality, hanya bisa dievaluasikan setelah dikonsumsi, contohnya ketepatan waktu, kecepatan layanan dan kerapihan hasil.

c) Credence quality, sukar dievaluasikan pelanggan sekalipun telah mengkonsumsi jasa, misalnya kualitas operasi bedah jantung.

\section{2) Functional Quality}

Yang berkaitan dengan kualitas cara penyampaian jasa.

3) Coorporate Image

Berupa profil, reputasi, citra umum dan daya tarik khusus suatu perusahaan.

Kualitas pelayanan memberikan suatu dorongan kepada konsumen atau dalam hal ini pengunjung untuk menjalin ikatan hubungan yang kuat dengan perusahaan pemberi pelayanan jasa. Ikatan hubungan yang baik ini akan memungkinkan perusahaan pemberi pelayanan jasa untuk memahami dengan seksama harapan konsumen serta kebutuhan mereka. Dengan demikian perusahaan dapat meningkatkan kepuasan konsumen dengan memaksimalkan pengalaman konsumen yang menyenangkan dan meminimumkan pengalaman konsumen yang kurang menyenangkan.

Apabila layanan yang diterima atau dirasakan sesuai dengan harapan konsumen, maka kualitas yang diterima atau dirasakan sesuai dengan harapan konsumen, maka kualitas layanan dipersepsikan sebagai kualitas ideal, tetapi sebaliknya jika layanan yang diterima atau dirasakan lebih rendah dari yang diharapkan maka kualitas layanan dipersepsikan rendah. Maka dapat disimpulkan bahwa kualitas pelayanan merupakan suatu penyajian produk atau jasa yang sesuai dengan standar perusahaan dan diupayakan dalam 
penyampaian produk dan jasa tersebut sama dengan apa yang diharapkan konsumen atau melebihi ekspetasi konsumen.

\section{Kinerja Bisnis}

Kinerja suatu bisnis merupakan segala sesuatu yang diinginkan oleh konsumen dalam produk ataupun jasa dengan memaksimalkan kualitas hasil yang nantinya diterima konsumen. Berikut adalah dimensi kinerja bisnis menurut Ranchod (2004) :

1) Efektifitas

Efektifitas terkait dengan perbandingan kondisi dan tingkat kesuksesan perusahaan.

Efektifitas perusahaan dapat dinilai dari tingkat pertumbuhan penjualan, pangsa pasar, retensi pelanggan, kepuasan dan tingkat komplain pelanggan.

2) Efisiensi

Efisiensi terkait dengan rasio input dan output yang bisa diukur dengan menggunakan pengembalian investasi, laba sebelum pajak, biaya tenaga kerja, tingkat produk gagal, atau tingkat penggunaan mesin perusahaan.

3) Adaptivitas

Adaptivitas terkait dengan kesuksesan perusahaan dalam merespon perubahan yang terjadi dilingkungannya. Penilaian adaptivitas bisa dilakukan dengan melihat rasio penjualan \& volume penjualan produk baru.

Kinerja bisnis merupakan rangkaian kegiatan yang dimulai dari perencanaan kinerja, pemantauan / peninjauan kinerja, penilaian kinerja dan tindak lanjut berupa pemberian penghargaan dan hukuman. Rangkaian kegiatan tersebut haruslah dijalankan secara berkelanjutan. Secara sederhana kinerja bisnis dapat diartikan sebagai hasil atau presentasi yang didapat suatu organisasi.

Menurut penelitian Narver dan Slater (2000) kinerja bisnis diukur dari profitabilitas dibandingkan dengan target yang telah ditetapkan. Ukuran kinerja bisnis yang sering dipakai adalah profitabilitas. Profitabilitas menunjukkan kemampuan perusahaan memperoleh laba dalam kaitannya dengan penjualan, total aktiva, maupun modal sendiri, jadi profitabilitas merupakan hasil bersih dari serangkaian kebijakan dan keputusan. Semakin tinggi profitabilitas maka semakin baik kinerja perusahaan. Meskipun masih 
profitabilitas dianggap sebagai aspek penting untuk mengukur kinerja perusahaan, akan tetapi hal tersebut belum mencukupi.

Pertumbuhan penjualan merupakan ukuran kinerja bisnis yang penting, karena dari pertumbuhan penjualan akan terlihat sejauh mana perusahaan mampu mempertahankan konsumen yang ada atau menambah jumlah konsumen baru. Dalam persaingan bisnis yang ketat perusahaan yang mampu meningkatkan pertumbuhan penjualannya berarti memiliki kinerja yang bagus. Croteau dan Bergeron (2001) menggunakan dua pendekatan untuk mendefinisikan kinerja bisnis. Pendekatan pertama adalah pendekatan obyektif. Pendekatan ini mengukur kinerja bisnis dengan melihat data keuangan perusahaan sebagai cerminan penggunaan kapasitas, pangsa pasar, dan profitabilitas. Sedangkan persepsi manajer atas perbuatan tersebut, seperti kualitas layanan, kepuasan pelangga, dan kepuasan karyawan, merupakan pendekatan subyektifnya.

\section{Keunggulan Bersaing}

Keunggulan bersaing merupakan strategi-strategi yang dilakukan perusahaan untuk menciptakan atau memberi nilai lebih kepada konsumennya dibandingkan dengan pesaing lainnya.

Menurut Bharadwaj (1993) dimensi keunggulan bersaing adalah :

1) Bernilai;

2) Berbeda dengan yang lain;

3) Tidak mudah digantikan;

Perusahaan yang memiliki keunggulan bersaing senantiasa memiliki kemampuan untuk memahami perubahan struktur pasar dan mampu memilih strategi pemasaran yang efektif serta efisien. Menurut Kotler (2001), pengertian keunggulan bersaing adalah keunggulan atas pesaing yang didapat dengan menyampaiakn nilai pelanggan yang lebih bersar, melalui harga yang lebih murah atau dengan menyediakan lebih banyak manfaat yang sesuai dengan penetapan harga yang lebih tinggi. Senada dengan itu (Jatmiko, 2004), menyatakan bahwa ada tiga pilihan strategi generik yang dapat dilakukan perusahaan untuk memperoleh keunggulan bersaing, yaitu:

1) Strategi kepemimpinan biaya rendah (the cost of leadership) 
Strategi kepemimpinan biaya rendah (the cost of leadership) yaitu serangkaian tindakan integratif untuk memproduksi dan menawarkan barang / jasa pada biaya paling rendah terhadap para pesaing dengan ciri-ciri yang dapat diterima oleh para pelanggan.

2) Strategi Differensiasi

Strategi Differensiasi yaitu serangkaian tindakan integratif yang dirancang untuk memproduksi dan menawarkan barang / jasa yang dianggap oleh para pelanggan berbeda dalam hal-hal penting dan unik bagi mereka.

3) Strategi Fokus

Strategi fokus yaitu serangkaian tindakan integratif yang dirancang untuk memproduksi dan menawarkan barang / jasa yang melayani kebutuhan segmen persaingan tertentu, atau pasar wilayah geografi tertentu (special product for special segment, or for special market).

Salah satu strategi bersaing yang dapat dipergunakan adalah dengan memberikan kelengkapan produk, fasilitas serta suasana yang lebih lengkap dan menarik yang dirancang sedemikian rupa, adapun faktor sosial, budaya, ekonomi dan pemilihan lokasi juga perlu diperhatikan, sehingga mampu bersaing dengan pesaing-pesaing yang lebih unggul. Karena keunggulan bersaing tidak dapat dipahami dengan memandang perusahaan sebagai suatu keseluruhan. Keunggulan bersaing berasal dari banyak aktivitas berlainan yang dilakukan oleh perusahaan untuk mendesain, memproduksi, memasarkan, menyerahkan, dan mendukung produknya.

\section{Penelitian Terdahulu}

Beberapa hasil penelitian yang relevan dengan penelitian ini yaitu :

\section{Tabel 1 Penelitian Terdahulu}

\begin{tabular}{|c|c|c|c|}
\hline $\begin{array}{c}\text { Judul dan } \\
\text { Nama Peneliti }\end{array}$ & $\begin{array}{c}\text { Variabel } \\
\text { Penelitian }\end{array}$ & Analisis & Hasil Penelitian \\
\hline $\begin{array}{l}\text { Peran Inovasi : } \\
\text { Pengembangan } \\
\text { Kualitas } \\
\text { Produk dan }\end{array}$ & $\begin{array}{l}\text { 1. Variabel } \\
\text { Dependen } \\
\text { Kualitas } \\
\text { Produk }\end{array}$ & $\begin{array}{l}\text { Penelitian ini dilakukan } \\
\text { pada perusahaan mebel } \\
\text { kayu di Jawa Timur. } \\
\text { Adapun yang menjadi }\end{array}$ & $\begin{array}{l}\text { Kemampuan inovasi } \\
\text { perusahaan baik inovasi produk } \\
\text { maupun inovasi proses sangat } \\
\text { rendah. Inovasi produk dan }\end{array}$ \\
\hline
\end{tabular}




\begin{tabular}{|c|c|c|c|}
\hline Kinerja Bisnis & Kinerja & & \\
\hline $\begin{array}{ll}\text { Sri } & \text { Hartini } \\
(2012) & \end{array}$ & $\begin{array}{l}\text { Perusahaan } \\
\text { 2. Variabel } \\
\text { Independen : } \\
\text { Inovasi Produk, } \\
\text { Inovasi Proses }\end{array}$ & $\begin{array}{lr}\text { perusahaan. } & \text { Dengan } \\
\text { menggunakan } & \text { analisis } \\
\text { SEM dan } & \text { metode } \\
\text { penelitian } & \text { secara } \\
\text { kuantitatif } & \end{array}$ & $\begin{array}{l}\text { signifikan terhadap kualitas } \\
\text { produk. Namun inovasi produk } \\
\text { dan inovasi proses ini tidak } \\
\text { berpengaruh terhadap kinerja } \\
\text { perusahaan. }\end{array}$ \\
\hline $\begin{array}{l}\text { Meningkatkan } \\
\text { Kinerja Bisnis } \\
\text { Melalui } \\
\text { Keunggulan } \\
\text { Bersaing } \\
\text { Kuliner Khas } \\
\text { Semarang } \\
\text { Bogy } \\
\text { Febriatmoko } \\
\text { dan Susilo Toto } \\
\text { Raharjo (2015) }\end{array}$ & $\begin{array}{l}\text { 1. Variabel } \\
\text { Dependen : } \\
\text { Kinerja Bisnis } \\
\text { 2. Variabel } \\
\text { Independen: } \\
\text { Keunggulan } \\
\text { Bersaing }\end{array}$ & $\begin{array}{l}\text { Penelitian ini dilakukan } \\
\text { pada makanan khas di } \\
\text { Semarang yaitu Lumpia, } \\
\text { Bandeng Presto dan } \\
\text { Wingko. Analisis yang } \\
\text { digunakan ialah SEM } \\
\text { AMOS dengan metode } \\
\text { penelitian kuantitatif. } \\
\text { Jumlah sample yang } \\
\text { digunakan adalah } 102 \\
\text { kuesioner }\end{array}$ & $\begin{array}{l}\text { Diantara } \\
\text { kewirausahaan dan orientasi } \\
\text { pasar hanya orientasi pasar } \\
\text { yang berpangaruh terhadap } \\
\text { keunggulan } \\
\text { Kemudian diantara orsaing. } \\
\text { kewirausahaan, orientasi pasar } \\
\text { dan keunggulan bersaing hanya } \\
\text { orientasi pasar yang tidak } \\
\text { berpangaruh terhadap kinerja } \\
\text { bisnis. }\end{array}$ \\
\hline $\begin{array}{l}\text { Pengaruh } \\
\text { Orientasi } \\
\text { Kewirausahaan } \\
\text { Dan Inovasi } \\
\text { Produk } \\
\text { Terhadap } \\
\text { Kinerja UKM } \\
\text { Kota Makassar } \\
\text { Indra Yanti } \\
\text { Sari (2016) }\end{array}$ & $\begin{array}{l}\text { 1. Variabel } \\
\text { Dependen : } \\
\text { Kinerja Usaha } \\
\text { 2. Variabel } \\
\text { Independen : } \\
\text { Orientasi } \\
\text { Kewirausahaan } \\
\text { dan Inovasi } \\
\text { Produk }\end{array}$ & 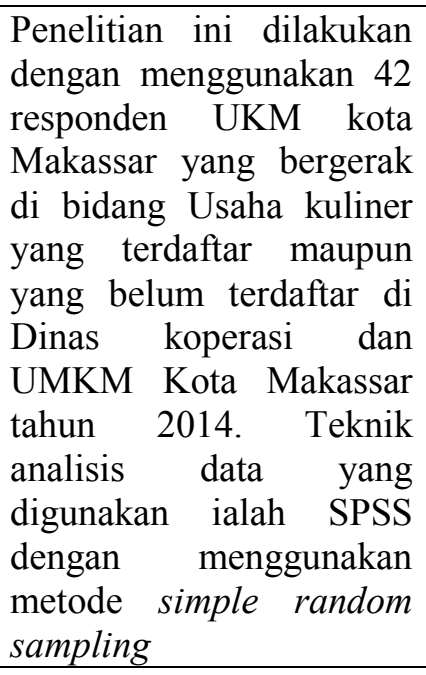 & $\begin{array}{l}\text { Orientasi Kewirausahaan dan } \\
\text { inovasi produk berpengaruh } \\
\text { secara simultan terhadap } \\
\text { Kinerja Perusahaan. Orientasi } \\
\text { Kewirausahaan berpengaruh } \\
\text { secara parsial terhadap Kinerja } \\
\text { Perusahaan. Inovasi Produk } \\
\text { berpengaruh secara parsial } \\
\text { terhadap Kinerja Perusahaan. }\end{array}$ \\
\hline $\begin{array}{l}\text { Pengaruh } \\
\text { Market } \\
\text { Orientation, } \\
\text { Inovasi Produk, } \\
\text { dan Kualitas } \\
\text { Produk } \\
\text { Terhadap } \\
\text { Kinerja Bisnis } \\
\text { Dalam } \\
\text { Mencinovasi } \\
\text { produktakan } \\
\text { Keunggulan } \\
\text { Bersaing }\end{array}$ & $\begin{array}{l}\text { 1. Variabel } \\
\text { Dependen : } \\
\text { Kinerja Bisnis } \\
\text { dan } \\
\text { Keunggulan } \\
\text { Bisnis } \\
\text { 2. Variabel } \\
\text { Independen : } \\
\text { Inovasi Produk } \\
\text { dan Kualitas } \\
\text { Produk }\end{array}$ & 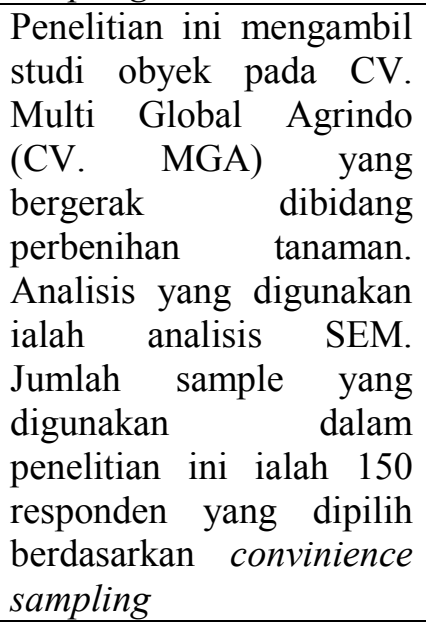 & $\begin{array}{l}\text { Orientasi pasar berpengaruh } \\
\text { positif secara langsung terhadap } \\
\text { keunggulan Bersaing dan tidak } \\
\text { berpengaruh secara tidak } \\
\text { langsung terhadap keunggulan } \\
\text { bersaing melalui kinerja bisnis. } \\
\text { Inovasi produk berpengaruh } \\
\text { positif secara langsung terhadap } \\
\text { keunggulan bersaing dan tidak } \\
\text { langsung Positif terhadap } \\
\text { keunggulan bersaing melalui } \\
\text { kinerja bisnis. Kualitas produk } \\
\text { berpengaruh positif secara } \\
\text { langsung terhadap keunggulan }\end{array}$ \\
\hline
\end{tabular}




\begin{tabular}{|c|c|c|c|}
\hline $\begin{array}{l}\text { Tulus Haryono } \\
\text { dan Sabar } \\
\text { Marniyati } \\
(2017)\end{array}$ & & & $\begin{array}{l}\text { bersaing dan secara tidak } \\
\text { langsung terhadap keunggulan } \\
\text { bersaing melalui kinerja bisnis. } \\
\text { Kinerja bisnis berpengaruh } \\
\text { secara langsung terhadap } \\
\text { keunggulan bersaing. }\end{array}$ \\
\hline $\begin{array}{l}\text { Pengaruh } \\
\text { Orientasi Pasar } \\
\text { dan Inovasi } \\
\text { Produk } \\
\text { Terhadap } \\
\text { Kinerja } \\
\text { Pemasaran }\end{array}$ & $\begin{array}{l}\text { 1. Variabel } \\
\text { Dependen : } \\
\text { Kinerja } \\
\text { Pemasaran } \\
\text { 2. Variabel } \\
\text { Independen : } \\
\text { Orientasi Pasar } \\
\text { dan Inovasi } \\
\text { Produk }\end{array}$ & $\begin{array}{lr}\text { Penelitian ini dilakukan } \\
\text { dengan menggunakan } \\
\text { sampel sebanyak } 42 \\
\text { pemilik industri rotan di } \\
\text { Desar } \\
\text { Kecamatan Trangsan } \\
\text { Kabupaten Sukoharjo. } \\
\text { Dengan jenis penelitian } \\
\text { kuantitatif dan teknik } \\
\text { simple random sampling. } \\
\text { Analisis yang digunakan } \\
\text { ialah SPSS. }\end{array}$ & $\begin{array}{l}\text { Orientasi pasar berpengaruh } \\
\text { positif signifikan terhadap } \\
\text { kinerja pemasaran. Dan } \\
\text { Inovasi produk berpengaruh } \\
\text { positif dan signifikan terhadap } \\
\text { kinerja pemasaran }\end{array}$ \\
\hline
\end{tabular}

\section{Kerangka Pemikiran Konseptual}

Berdasarkan teori sebelumnya mengenai variabel inovasi produk dan kualitas pelayanan terhadap kinerja bisnis melalui keunggulan bersaing, maka kerangka konsep yang akan diterapkan dalam penelitian ini adalah :

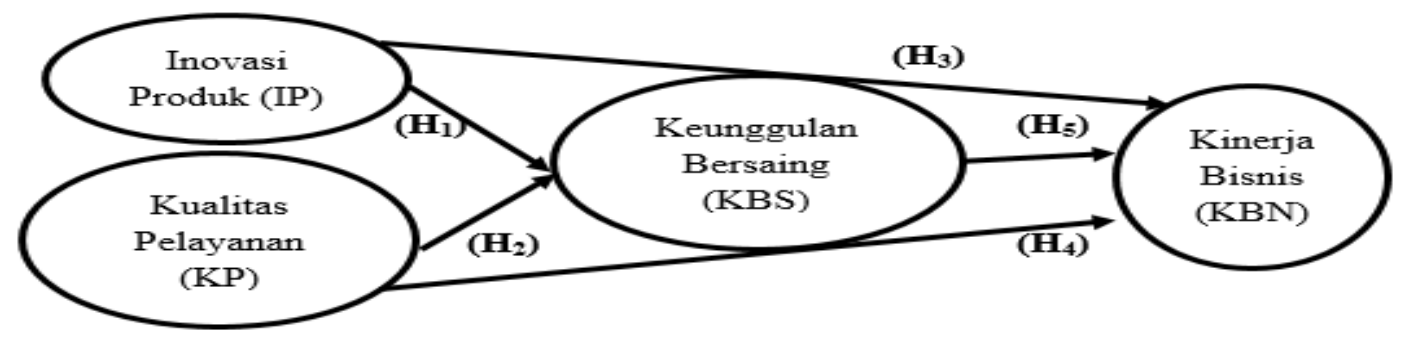

\section{Gambar 1 Kerangka Konsep}

\section{METODE PENELITIAN}

\section{Desain Penelitian}

Penelitian ini merupakan penelitian kuantitatif, Penelitian ini terdiri dari dua variabel yaitu inovasi produk dan kualitas pelayanan sebagai variabel bebas (X), 
keunggulan bersaing sebagai variabel intervening (M), dan kinerja bisnis sebagai variabel terikat (Y).

\section{Teknik Pengambilan Data}

Dalam penelitian ini, analisis pengaruh variabel inovasi produk dan kualitas pelayanan terhadap keunggulan bersaing dan kinerja bisnis akan dianalisis dengan menggunakan teknik analisis Structural Equation Modelling (SEM). Teknik pengambilan sampel dalam penelitian ini dilakukan dengan metode nonprobability sampling dengan accidental sampling. Penelitian ini menggunakan 100 responden sebagai sampel agar dimungkinkan hasil lebih akurat. Karena dalam penelitian ini menggunakan empat variabel (independen dan dependen) maka jumlah sampel yang diperlukan sebanyak 100. Metode pengumpulan data pada penelitian ini adalah dengan menggunakan Kuisioner, yaitu data yang didapatkan dengan cara memberikan beberapa pertanyaan atau pertanyaan tertulis kepada responden untuk dijawab.

\section{Definisi Operasional}

Untuk memberikan gambaran yang lebih jelas tentang variabel penelitian, maka disajikan tabel sebagai berikut:

\section{Tabel 2}

\section{Definisi Operasional Variabel}

\begin{tabular}{|c|c|c|c|}
\hline Variabel & Konsep Variabel & Indikator & Sumber \\
\hline \multirow{3}{*}{$\begin{array}{c}\text { Inovasi } \\
\text { Produk } \\
\quad\left(\mathrm{X}_{1}\right)\end{array}$} & \multirow{3}{*}{$\begin{array}{l}\text { Peran inovasi dalam mendongkrak } \\
\text { kinerja usaha meliputi seluruh } \\
\text { aspek penting yang bisa } \\
\text { memberikan nilai tambah pada } \\
\text { daya saing perusahaan. }\end{array}$} & Keunggulan Produk & \multirow{3}{*}{$\begin{array}{l}\text { Gatignon dan } \\
\text { Xuereb (1997) }\end{array}$} \\
\hline & & Kesamaan Produk & \\
\hline & & Biaya Produk & \\
\hline \multirow{4}{*}{$\begin{array}{c}\text { Kualitas } \\
\text { Pelayanan } \\
\quad\left(\mathrm{X}_{2}\right)\end{array}$} & \multirow{4}{*}{$\begin{array}{l}\text { Kualitas pelayanan adalah } \\
\text { kesesuaian dan derajat } \\
\text { kemampuan untuk digunakan dari } \\
\text { keseluruhan karakteristik produk } \\
\text { dan jasa yang disediakan dalam } \\
\text { pemenuhan harapan yang } \\
\text { dikehendaki konsumen. }\end{array}$} & Bukti Fisik (Tangible) & \multirow{4}{*}{ Parasuraman (2001) } \\
\hline & & $\begin{array}{l}\text { Reliabilitas } \\
\text { (Reliability) }\end{array}$ & \\
\hline & & $\begin{array}{c}\text { Daya Tanggap } \\
\text { (Responsiveness) }\end{array}$ & \\
\hline & & Jaminan (Assurance) & \\
\hline
\end{tabular}




\begin{tabular}{|c|c|c|c|}
\hline & & Empati (Empathy) & \\
\hline \multirow{3}{*}{$\begin{array}{l}\text { Kinerja } \\
\text { Bisnis } \\
\text { (Y) }\end{array}$} & \multirow{3}{*}{$\begin{array}{l}\text { Kinerja suatu bisnis merupakan } \\
\text { segala sesuatu yang diinginkan } \\
\text { oleh konsumen dalam produk } \\
\text { ataupun jasa dengan } \\
\text { memaksimalkan kualitas hasil } \\
\text { yang nantinya diterima konsumen }\end{array}$} & Efektivitas & \multirow{3}{*}{ Ranchod (2004) } \\
\hline & & Efisien & \\
\hline & & Adaptivitas & \\
\hline \multirow{3}{*}{$\begin{array}{c}\text { Keunggulan } \\
\text { Bersaing } \\
\text { (M) }\end{array}$} & \multirow{3}{*}{$\begin{array}{l}\text { Keunggulan bersaing merupakan } \\
\text { strategi-strategi yang dilakukan } \\
\text { perusahaan untuk menciptakan } \\
\text { atau memberi nilai lebih kepada } \\
\text { konsumennya dibandingkan } \\
\text { dengan pesaing lainnya. }\end{array}$} & Bernilai & \multirow{3}{*}{ Bharadwaj (1993) } \\
\hline & & $\begin{array}{c}\text { Berbeda dengan yang } \\
\text { lain }\end{array}$ & \\
\hline & & $\begin{array}{l}\text { Tidak mudah } \\
\text { digantikan }\end{array}$ & \\
\hline
\end{tabular}

\section{Teknik Analisis Data}

Tujuan dari metode analisis data ini adalah untuk menginterpretasikan dan menarik kesimpulan dari sejumlah data yang terkumpul. SEM merupakan teknik analisis yang memungkinkan pengujian sebuah rangkaian hubungan secara simultan. Dalam analisis SEM, pengujian model pengukuran digunakan untuk menguji validitas dan reliabilitas indikator pada masing-masing konstruk. Pengujian model pengukuran dilakukan sebanyak 2 kali yaitu pengujian model pengukuran konstruk eksogen dan pengujian model pengukuran konstruk endogen. Model memenuhi kriteria goodness of fit model apabila probabilitas model $>0,05$ dan rmsea model $>0,08$.

\section{HASIL DAN PEMBAHASAN}

\section{Uji Prasyarat Analisis SEM}

Uji Normalitas dalam analisis SEM dimaksudkan untuk mengetahui normal tidaknya distribusi penelitian masing-masing variabel. Evaluasi normalitas dilakukan dengan menggunakan kriteria critical ration skewness value, data dikatakan berdistribusi normal jika nilai $\mathrm{p}$ value hasil pengujian $>0,05$ (Ghozali, 2016). Berikut ini adalah hasil uji normalitas data pada model : 


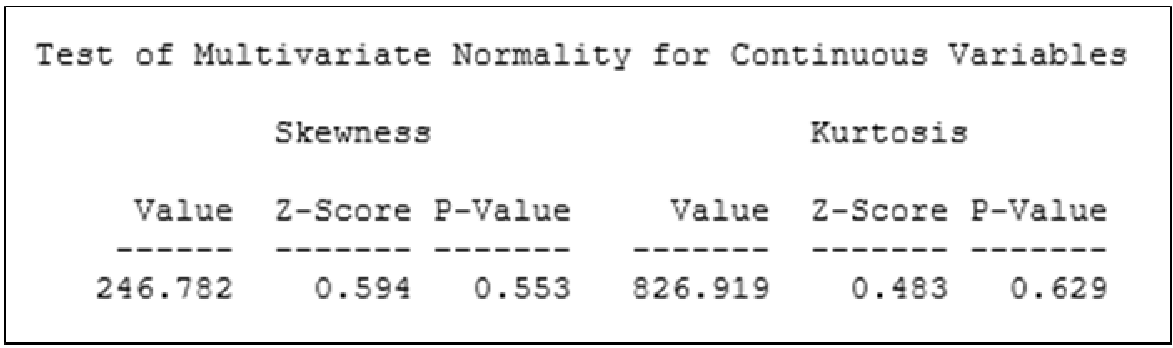

Gambar 2 Hasil Uji Normalitas

Sumber: Data Kuisioner, diolah 2018

Hasil uji normalitas menunjukkan bahwa nilai $\mathrm{p}$ value skewness sebesar 0,553 dan

nilai $\mathrm{p}$ value kurtosis sebesar 0,629 telah melebihi 0,05 sehingga dapat disimpulkan bahwa data yang di analisis telah memenuhi asumsi normalitas.

Uji Multikolinearitas dilakukan dengan melihat nilai korelasi antar variabel eksogen. Model dinyatakan terbebas dari multikolinearitas jika nilai korelasi antar variabel eksogen $<0,9$. Hasil uji multikolienaritas pada menunjukkan bahwa besar korelasi antara variabel Inovasi Produk dan Kualitas Pelayanan adalah 0,77 yang berarti tidak ada variabel eksogen yang memiliki korelasi $>0,9$, hal ini berarti tidak ada multikolinearitas dalam model SEM.

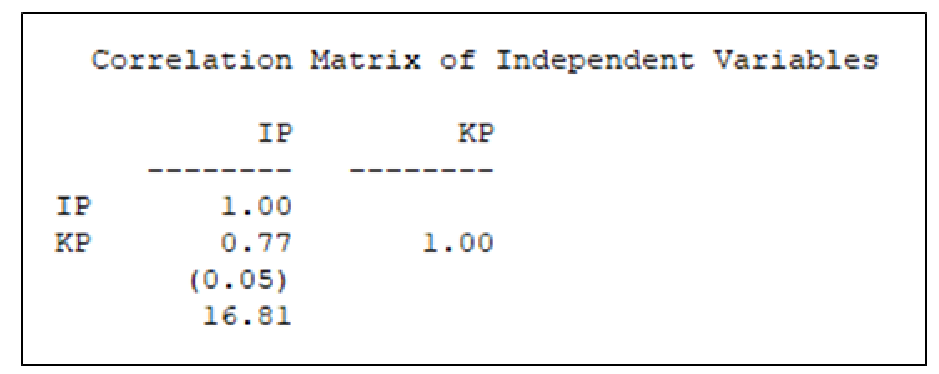

Gambar 3 Hasil Uji Multikolinearitas

Sumber: Data Kuisioner, diolah 2018

\section{Uji Reabilitas}

Uji reliabilitas konstruk eksogen dilakukan dengan menghitung nilai AVE dan CR konstruk eksogen. Dalam pengujian ini konstruk eksogen dinyatakan reliabel jika AVE model $>0,5$ dan CR model $>0,7$. 
Tabel 3

Hasil Perhitungan Nilai CR dan AVE Konstruk

\begin{tabular}{|l|c|c|}
\hline \multicolumn{1}{|c|}{ Variabel } & AVE & CR \\
\hline Inovasi Produk & 0.787 & 0.966 \\
\hline Kualitas Pelayanan & 0.672 & 0.985 \\
\hline Keunggulan Bersaing & 0.801 & 0.966 \\
\hline Kinerja Bisnis & 0.688 & 0.961 \\
\hline
\end{tabular}

Sumber: Data Kuisioner, diolah 2018

Hasil perhitungan nilai AVE konstruk endogen telah melebihi 0,5 dan nilai CR konstruk endogen telah melebihi 0,7 . Hal ini menunjukkan bahwa seluruh dimensi dalam konstruk endogen telah reliabel.

\section{Uji Kecocokan Model Struktural}

Uji kecocokan model struktural dalam analisis SEM dilakukan dengan melihat beberapa kriteria Goodness of fit model (GOF) seperti berikut :

\section{Tabel 4}

Hasil Goodness of fit model (GOF)

\begin{tabular}{lccc}
\hline \multicolumn{1}{c}{ Goodness Of Fit Indeks (GOF) } & Cut Of Value & $\begin{array}{c}\text { Hasil } \\
\text { Analisis }\end{array}$ & $\begin{array}{c}\text { Evaluasi } \\
\text { Model }\end{array}$ \\
\hline Chi Square & $<3$ & 437,67 & Poor \\
df (degree of freedom) & $<5$ & 3,44 & Good \\
Goodness Of Fit index (GFI) & $0-1$ & 0,76 & Marginal \\
Adjusted Goodness of Fit Index (AGFI) & $>0,9$ & 0,72 & Poor \\
Comparative Fit Index (CFI) & $0-1$ & 0,99 & Good \\
Root mean square error of approximation (RMSEA) & $<0,05$ & 0,052 & Good \\
Root Mean Square Residual (RMR) & $<0.05$ & 0,042 & Good \\
Incremental Fit Index (IFI) & $>0,90$ & 0,99 & Good \\
Normed Fit Index (NFI) & $\geq 0,90$ & 0,97 &
\end{tabular}


Tucker Lewis Index (TLI) atau Non- Normed Fit Index $>0,95$

0,99

Good (NNFI)

$\begin{array}{lccr}\text { Parsimonious Normal Fit Index (PNFI) } & 0,60-0,90 & 0,88 & \text { Marginal } \\ \text { Parsimonious Goodness of Fit Index (PGFI) } & 0-1 & 0,64 & \text { Marginal }\end{array}$

Sumber: Data Kuisioner, diolah 2018

Namun demikian, kriteria goodness of fit model yang sebaiknya harus terpenuhi adalah nilai probabilitas model di atas 0,05 . Hal ini karena model dengan probabilitas di atas 0,05 akan memiliki matriks kovarian yang tidak berbeda dengan matirks kovarian populasi sebenarnya sehingga hasil analisis akan memberikan kesimpulan analisis yang tepat. Hasil estimasi model struktural berikut hasil uji goodness of fit model dapat dilihat sebagai berikut:

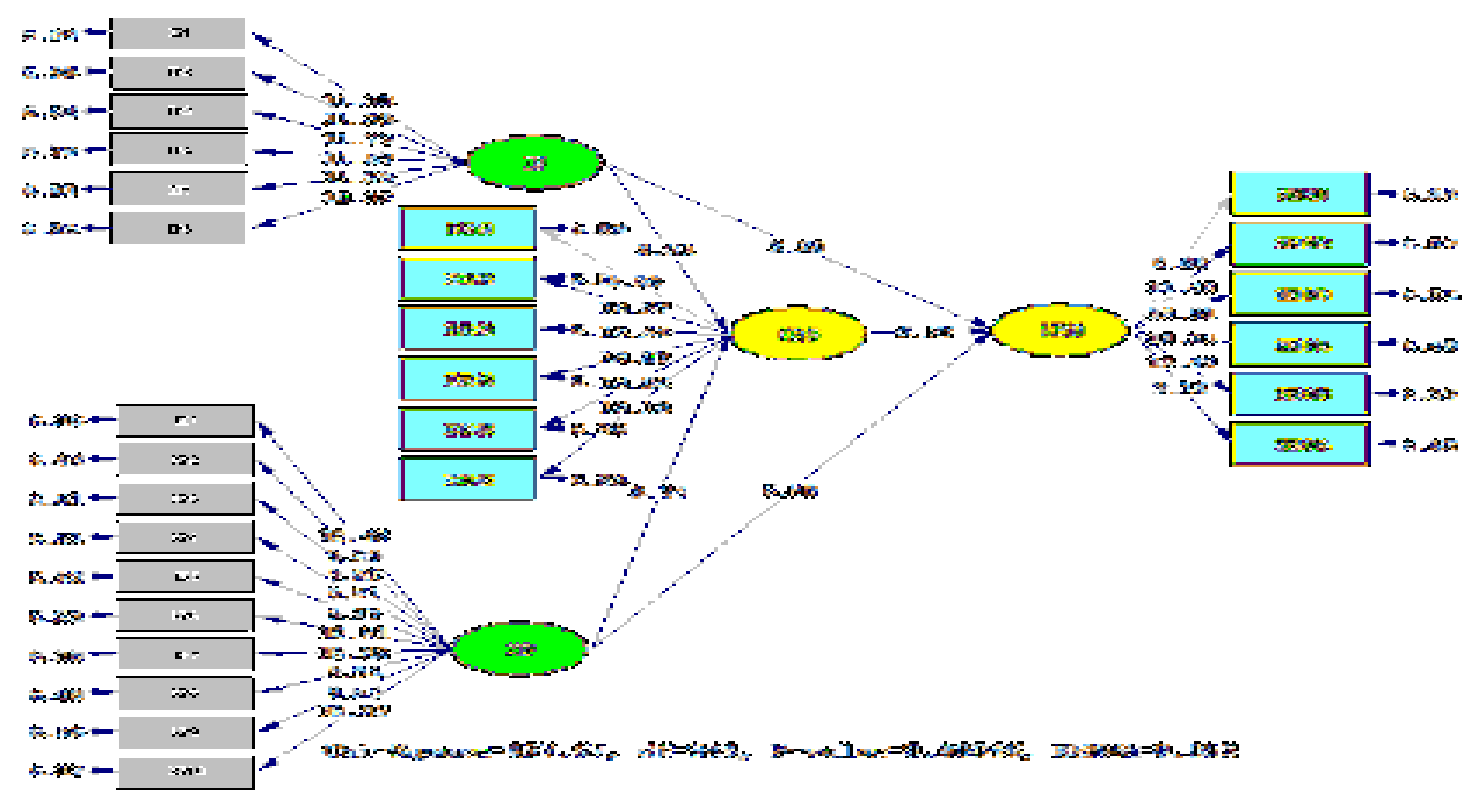

\section{Gambar 4 Hasil Estimasi Model Struktural}

Sumber: Data Kuisioner, diolah 2018

Berdasarkan hasil estimasi model struktural, model struktural belum begitu baik dalam memenuhi kriteria Goodness of fit model, yaitu nilai probabilitas model masih di bawah 0,05 meskipun rmsea model telah $<0,08$. Untuk meningkatkan goodness of fit model, dapat dilakukan modifikasi model dengan melakukan penambahan jalur 
berdasarkan saran Lisrel yang terdapat dalam Tabel modification indicase. Hasil modifikasi model dapat dilihat pada Gambar berikut :

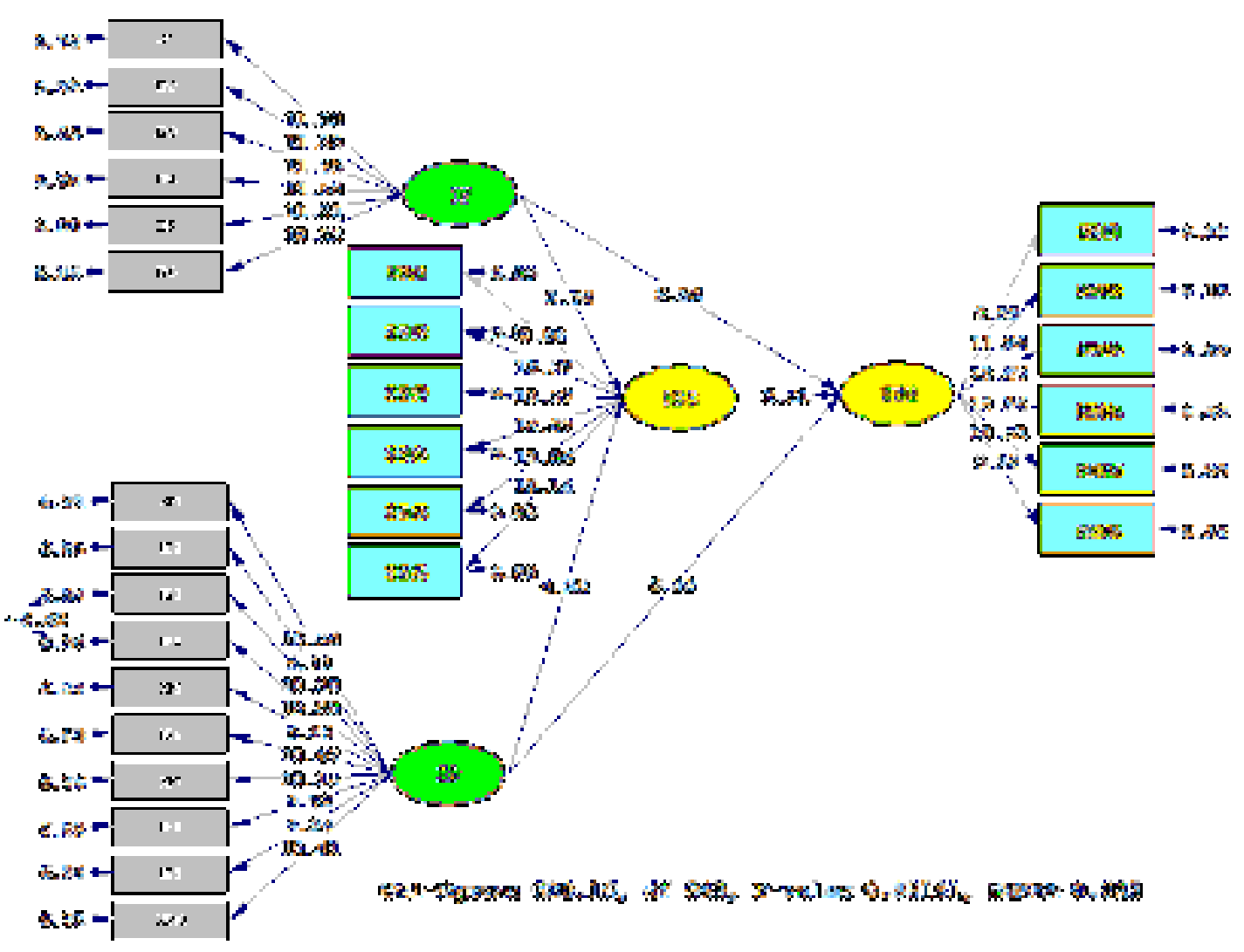

\section{Gambar 5 Hasil Modifikasi Model}

Sumber: Data Kuisioner, diolah 2018

Berdasarkan Gambar 5, setelah model dimodifikasi, model telah memiliki nilai probabilitas $>0,05$ dan rmsea model telah $<0,08$ yang berarti model telah memenuhi kriteria Goodness Of Fit model (GOF) dengan baik, sehingga model telah layak digunakan untuk menguji hipotesis penelitian.

\section{Uji Signifikansi}

Uji signifikansi bertujuan untuk menguji ada tidaknya pengaruh signifikan variabel eksogen terhadap variabel endogen. Hipotesis yang dibangun dalam pengujian ini adalah sebagai berikut :

Ho : Tidak terdapat pengaruh signifikan variabel eksogen terhadap variabel endogen 
Ha : Terdapat pengaruh signifikan variabel eksogen terhadap variabel endogen

Dengan taraf signifikan sebesar 0,05 maka Ho akan ditolak jika nilai t hitung > 1,96, sedangkan jika nilai signifikan $\mathrm{t}$ hitung $<1,96$ maka Ho tidak ditolak.

\section{Tabel 5}

\section{Hasil Uji Signifikansi}

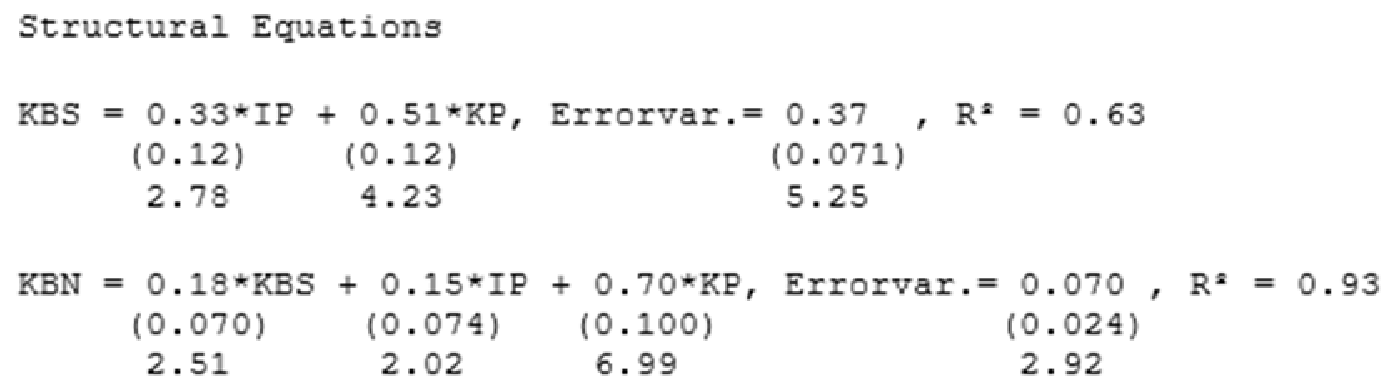

Sumber: Data Kuisioner, diolah 2018

\section{Pengujian Hipotesis}

Hipotesis $1\left(\mathrm{H}_{1}\right)$ : Inovasi Produk (IP) berpengaruh positif dan signifikan terhadap

\section{Keunggulan Bersaing (KBS)}

Nilai t statistik pengaruh Inovasi Produk terhadap Keunggulan Bersaing adalah sebesar 2,78 dengan koefisien persamaan struktural bertanda positif. Oleh karena t hitung $>$ 1,96 dan koefisien persamaan struktural bertanda positif maka Ho ditolak dan disimpulkan bahwa Inovasi Produk berpengaruh positif dan signifikan terhadap Keunggulan Bersaing. Semakin tinggi Inovasi Produk yang dikeluarkan maka semakin tinggi Keunggulan Bersaing PT Railink, begitu sebaliknya. Hal ini mendukung hipotesis 1 dalam penelitian ini sehingga hipotesis $\left(\mathrm{H}_{1}\right)$ diterima.

\section{Hipotesis $2\left(\mathrm{H}_{2}\right)$ : Kualitas Pelayanan (KP) berpengaruh positif dan signifikan terhadap Keunggulan Bersaing (KBS)}

Nilai t statistik pengaruh Kualitas Pelayanan terhadap Keunggulan Bersaing adalah sebesar 4,23 dengan koefisien persamaan struktural bertanda positif. Oleh karena t hitung $>$ 1,96 dan koefisien persamaan struktural bertanda positif maka Ho ditolak dan disimpulkan bahwa Kualitas Pelayanan berpengaruh positif dan signifikan terhadap 
Keunggulan Bersaing. Semakin tinggi Kualitas Pelayanan yang diberikan maka semakin tinggi keunggulan bersaing PT Railink, begitu sebaliknya. Hal ini mendukung hipotesis 2 dalam penelitian ini sehingga hipotesis $\left(\mathrm{H}_{2}\right)$ diterima.

Hipotesis 3 (H3) : Inovasi Produk (IP) berpengaruh positif dan signifikan terhadap Kinerja Bisnis (KBN)

Nilai t statistik pengaruh inovasi produk terhadap Kinerja Bisnis adalah sebesar 2,02 dengan koefisien persamaan struktural bertanda positif. Oleh karena t hitung $>1,96$ dan koefisien persamaan struktural bertanda positif maka Ho ditolak dan disimpulkan bahwa Inovasi Produk berpengaruh positif dan signifikan terhadap Kinerja Bisnis. Semakin tinggi Inovasi Produk yang dikeluarkan maka semakin tinggi Kinerja Bisnis PT Railink, begitu sebaliknya. Hal ini mendukung hipotesis 3 dalam penelitian ini sehingga hipotesis $\left(\mathrm{H}_{3}\right)$ diterima.

\section{Hipotesis $4\left(\mathrm{H}_{4}\right)$ : Kualitas Pelayanan (KP) berpengaruh positif dan signifikan terhadap Kinerja Bisnis (KBN)}

Nilai t statistik pengaruh Kualitas Pelayanan terhadap Kinerja Bisnis adalah sebesar 6,99 dengan koefisien persamaan struktural bertanda positif. Oleh karena t hitung $>1,96$ dan koefisien persamaan struktural bertanda positif maka Ho ditolak dan disimpulkan bahwa Kualitas Pelayanan berpengaruh positif dan signifikan terhadap Kinerja Bisnis. Semakin tinggi kualitas pelayanan yang diberikan maka semakin tinggi Kinerja Bisnis PT Railink, begitu sebaliknya. Hal ini mendukung hipotesis 4 dalam penelitian ini sehingga hipotesis $\left(\mathrm{H}_{4}\right)$ diterima.

\section{Hipotesis 5 (H5) : Keunggulan Bersaing (KBS) berpengaruh positif dan signifikan terhadap Kinerja Bisnis (KBN)}

Nilai t statistik pengaruh Keunggulan Bersaing terhadap Kinerja Bisnis adalah sebesar 2,51 dengan koefisien persamaan struktural bertanda positif. Oleh karena t hitung > 1,96 dan koefisien persamaan struktural bertanda positif maka Ho ditolak dan disimpulkan bahwa Keunggulan Bersaing berpengaruh positif dan signifikan terhadap Kinerja Bisnis. Semakin tinggi Keunggulan Bersaing maka semakin tinggi Kinerja Bisnis PT Railink, 
begitu sebaliknya. Hal ini mendukung hipotesis 5 dalam penelitian ini sehingga hipotesis $\left(\mathrm{H}_{5}\right)$ diterima.

\section{SIMPULAN}

Berdasarkan analisis data dan pembahasan maka dapat disimpulkan sebagai berikut :

1) Inovasi produk berpengaruh positif dan signifikan terhadap keunggulan bersaing. Semakin tinggi inovasi produk maka keunggulan bersaing PT Railink semakin tinggi begitu sebaliknya.

2) Kualitas pelayanan berpengaruh positif dan signifikan terhadap terhadap keunggulan bersaing. Semakin mengingkat kualitas pelayanan maka keunggulan bersaing PT Railink semakin tinggi begitu sebaliknya.

3) Inovasi produk berpengaruh positif dan signifikan terhadap kinerja bisnis. Semakin tinggi inovasi produk maka kinerja bisnis PT Railink akan semakin tinggi begitu sebaliknya.

4) Kualitas pelayanan berpengaruh positif dan signifikan terhadap terhadap kinerja bisnis. Semakin meningkat kualitas pelayanan PT Railink maka semakin tinggi kinerja bisnisnya, begitu sebaliknya.

5) Keunggulan bersaing berpengaruh positif dan signifikan terhadap kinerja bisnis. Semakin tinggi keunggulan bersaing PT Railink maka semakin tinggi kinerja bisnis begitu sebaliknya.

Keunggulan bersaing mampu memediasi inovasi produk dan kualitas pelayanan terhadap kinerja bisnis PT Railink. Hal ini menjelaskan bahwa inovasi produk dan kualitas pelayanan akan bisa menyebabkan kinerja bisnis meningkat setelah mampu meningkatkan keunggulan bersaing PT Railink. 


\section{DAFTAR PUSTAKA}

A, Parasuraman. 2001. The Behavioral Consequenses of Service Quality, Journal Of Marketing. Vol.60

Bharadwaj, Sundar G, P.R.Varadarajan, \& Fahly, Jihn. 1993. Sustainable Competitive Advantage in Service Industries: A Conceptual Model and Research Propositions. Journal of Marketing, Vol.57, h83-99

Croteau, Anne Marie, dan Bergeron, F. 2001. An information technology trilogy: business strategy, technological deployment and organizational performance. Journal of Strategic Information Systems. h77-99

Febriatmoko, Bogy dan Susilo Toto Raharjo. Meningkatkan Kinerja Bisnis Melalui Keunggulan Bersaing Kuliner Khas Semarang. Semarang. CBAM UNISSULA. Vol.2 no.1, h139-144

Gatignon, Hubert and Jean-Marc Xuereb, Strategy Orientation of the Firm and New Product Performance. 1997. Journal of Marketing Research. Vol. 34, h77-90

Ghozali, Imam. 2016. Aplikasi Analisis Multivariate dengan Program IBM SPSS 23. Semarang. BPFE Universitas Diponegoro

Gilang Prasidya Jati. 2014. Pengaruh Keunggulan Bersaing Melalui Kinerja Bersaing (Studi Kasus Warung Makan Di Wilayah Tlogosari Semarang). Semarang. Fakultas Ekonomika dan Bisnis. Universitas Diponegoro

Gronroos, Michael, 1990. Perceived Service Quality Model. California. Published Ohio University Press

Hardiansyah. 2011. Kualitas Pelayanan Publik. Yogyakarta. Gava Media

Hartini, Sri. 2012. Peran Inovasi : Pengembangan Kualitas Produk dan Kinerja Bisnis. Surabaya. Jurnal Management \& Kewirausahaan. Vol.14 no.1, h82-88

Hartini, Sri. 2012. Peran Inovasi : Pengembangan Kualitas Produk dan Kinerja Bisnis. Surabaya. Jurnal Management \& Kewirausahaan. Vol.14 no.1, h82-88 
Haryono, Tulus dan Sabar Marniyati. 2017. Pengaruh Market Orientation, Inovasi Produk, dan Kualitas Produk Terhadap Kinerja Bisnis Dalam Menciptakan Keunggulan Bersaing. Surakarta. Jurnal Bisnis \& Management. Vol.17 no.2, h51 -68

Hasanah, Fahmi Sulus. 2017. Pengaruh Orientasi Pasar dan Inovasi Produk Terhadap Kinerja Pemasaran. Surakarta. Fakultas Ekonomi Dan Bisnis Islam Institut Agama Islam Negeri Surakarta

Hult, G.T.M., Hurley, R.F. \& Knight, G.A. 2004. Innovativeness: Its Antecedents and Impact on Business Performance. Industrial Marketing Management, 33 (5): $429-38$

Jatmiko, RD. 2004. Manajemen Strategi. Jakarta. Salemba Empat. Edisi 1

Kotler, Philip dan Gary Armstrong. 2004. Dasar-dasar Pemasaran. Jakarta. PT. Indeks Gramedia. Jilid 1. Edisi Kesembilan

Kotler, Philip. 2001. Manajemen Pemasaran: Analisis, Perencanaan, Implementasi dan Kontrol. Jakarta. PT. Prehallindo

Lovelock, C, John Wirtz, 2011. Pemasaran Jasa Perspektif. Jakarta. Erlangga. Edisi 7

Narver, J.C, \& Slater, S.F \& maclachlan, D.L. 2000. Total Market Orientation, Business Performance And Innovation. Marketing Science Institute, Report no 116

Ranchod, A. 2004. Marketing Strategies: a Twenty-First A Century Approach. New Jersey: Pren-tice Hall

Sari, Indra Yanti. 2016. Pengaruh Orientasi Kewirausahaan Dan Inovasi Produk Terhadap Kinerja UKM Kota Makassar. Makassar. Fakultas Ekonomi dan Bisnis Islam UIN Alauddin Makassar

Tjiptono, Fandy. 2014. Pemasaran Jasa - Prinsip. Penerapan, dan Penelitian. Yogyakarta. Andi Offset 
Widianti, Atik. 2013. Tinjauan Kepuasan Konsumen pada Program Winback Telkomvision: Studi pada CV. Bunda Cirebon. Bandung. Penelitian Proyek Akhir Manajemen Pemasaran Universitas Telkom. 